\title{
The behaviour of alkali activated materials based on calcium clay at elevated temperatures
}

\author{
Michat Łach $^{1}$, Dariusz Mierzwiński ${ }^{1,{ }^{*}}$, Kinga Korniejenko ${ }^{1}$, Artur Stanek $^{2}$ and Janusz \\ Mikuła $^{1}$ \\ ${ }^{1}$ University of Technology, Institute of Materials Engineering, Faculty of Mechanical Engineering, 37 \\ Jana Pawła II St., 31-864 Cracow, Poland \\ ${ }^{2}$ WKG Ltd, L.P., 69 Działoszyńska St., 98-355 Raciszyn, Poland
}

\begin{abstract}
Growing environmental awareness and importance of development of sustainable construction materials for decreasing environmental impact of construction industry are main motivators to research work on new, innovative materials' solutions. The most promise alternative solutions are technologies based on alkali-activated. This process allows to obtain the fire-resistant materials. However, it is a rather complex process, when using waste materials. Nevertheless, wastebased Alkali Activated Materials AAMs can be optimized and tailored to desired applications. The main objective of the article is to analyse the possibilities of using calcium clay from the city called Raciszyn, Poland for the AAMs manufacturing and the properties of the obtained material, including thermal resistance. The results show that new materials have good mechanical properties at elevated temperatures. The materials were tested at $800^{\circ} \mathrm{C}$, depending on the used alkaline activator, they were characterized by bending strength in the range: $2.7-6.2 \mathrm{MPa}$. A permanent change in dimensions due to heating was also determined. Due to the very high fire resistance, materials referred to as AAMs, also produced from waste such as calcium clay, can find a variety of applications in construction and where it is necessary to ensure the passive fire protection.
\end{abstract}

\section{Introduction}

Geopolymers are aluminosilicate materials that are created by means of synthesis the reaction of aluminosilicate powder in an alkaline solution. They are not generated as a result of geological processes but are obtained artificially. Their structure is very similar to that of natural stones, which is why geopolymers are often referred to as "artificial stones". They are included in the group of inorganic polymers. In contrast to traditional hydraulic binders, geopolymers are created because of the reaction of mineral polycondensation known as "geosynthesis". In the case of traditional binders, their hardening is brought about by the hydration of calcium aluminates and calcium silicates [1$3]$.

\footnotetext{
* Corresponding author: dariusz.mierzwinski@mech.pk.edu.pl
} 
The composition of geopolymer materials mainly consists of the following: silicon, aluminum and an alkaline element of the sodium or potassium type. They consist of long chains-copolymers of silicon and aluminum oxides as well as of metal cations which serve to stabilize them, being most commonly sodium, potassium, (lithium or calcium) and bound water. Binding takes place in strongly alkaline aqueous solutions in which reactive aluminosilicates are dissolved and subsequently in the tetrahedrons polycondensation process $\left[\mathrm{SiO}_{4}\right]^{4},\left[\mathrm{AlO}_{4}\right]^{5-}$ whereby they join by their corners, creating amorphous or subcrystalline spatial aluminosilicate structures [1-3]. The applications of geopolymers are becoming wider and hitherto-unused waste materials of various types are being used with increasingly frequency for their production. Calcium clay obtained during the limestone production and purification may become one of such materials. It is composed of aluminosilicates and a large amount of calcium (in the form of $\mathrm{CaCO}_{3}$ ). Research has shown [4] geopolymers based on volatile ashes containing high volume of calcium are a potential fireproof material, as they show good fire resistance of up to $400^{\circ} \mathrm{C}$. They can be also hardened at room temperature. The use of volatile ashes with a high calcium content as a raw material to produce fireproof geopolymers is a relatively new approach, as so far most of the research concerned low-calcium ashes. The use of calcium-containing raw materials or the introduction of calcium additives has a significant impact on the properties of the obtained geopolymers. The addition of lime powder to geopolymers based on volatile ashes increases their compression strength but with addition of 20 and $25 \%$, their workability decreases [6]. Aluminum-calcium cements increase compression strength values for both volatile-ash-based and metakaolin-based geopolymers. An addition of $6 \%$ calcium-aluminum cement with content $\mathrm{Al}_{2} \mathrm{O}_{3}$ above $69 \%$ causes a $40 \%$ increase in compression strength of geopolymers based on volatile ashes. In the case of metakaolinbased geopolymers, the highest increase in compression strength (that of 35\%) was observed in the case of a $6 \%$ addition of cement containing $\mathrm{Al}_{2} \mathrm{O}_{3}$ above $41 \%$ and $\mathrm{CaO}$ above $35 \%$ [8]. Data obtainable in the reference literature also mention the beneficial effect of aluminum-calcium cements on the process of limiting efflorescence on geopolymers. These phenomena, however, are not completely explained and they require further detailed research. Also, the use of slag as a reinforcing admixture and a parameter modifier is mainly based on the introduction of calcium into the geopolymerization process. Calciumcontaining gels help to create a more compact microstructure than those that consist solely of volatile ashes. This is one of the main reasons for the high resistance achieved in slagcontaining geopolymers [9-10]. Studies have shown that alkali-activated aluminosilicate composites (based on slags), once exposed to high temperatures of up to $1200^{\circ} \mathrm{C}$, show very good mechanical properties, comparable with those of materials not subjected to thermal loads. They can be used in applications in which traditional composites based on Portland cement would be likely to fail [7]. Studies on geopolymers [5] in which mixtures of metakaolin and volatile ashes had been used as raw materials showed that the bond strength of geopolymer mortar on cement mortar or concrete substrate is close to or even higher than that obtained in the case of commercially used repair mortars in the temperature range of $25-700^{\circ} \mathrm{C}$.

This paper describes the process of generation and testing of the properties of alkaliactivated calcium clay subjected to sintering at $1100^{\circ} \mathrm{C}$.

\section{Experiments}

The post-production clay, weighing about $50 \mathrm{~kg}$, was taken from the Jurassic limestone deposit in "Raciszyn II" which pertains to the WKG Company. Calcareous clay is one of the by-products of the limestone processing plant. The cleaned limestone with a fraction of 2-30 $\mathrm{mm}$ is an excellent feed for the vertical roller mill to produce high-quality limestone 
powder, while lime-quartz sand - once dried and fractioned makes for a light filler for mortars and plasters. The third recovered product is clay, which was the object of research conducted by WKG in cooperation with the Cracow University of Technology.

The clay in the delivery state, i.e. in the form of wet caked patches, was dried at $105^{\circ} \mathrm{C}$ for $48 \mathrm{~h}$, and subsequently pre-milled using the RETSCH ZM 200 ultra-centre mill and ground in a roller mill. The product prepared in this way was roasted at $750^{\circ} \mathrm{C}$ for a period of 2 hours and cooled down together with the furnace to ambient temperature.

To prepare samples for testing the mechanical properties of geopolymers, samples were made based on roasted clay at a temperature of $750^{\circ} \mathrm{C}$ and regular construction sand; they were then activated with a $10 \mathrm{M} \mathrm{NaOH}$ solution and a mixture of solutions containing $10 \%$ solution of $10 \mathrm{M} \mathrm{KOH}$ and a $90 \%$ solution of $10 \mathrm{M} \mathrm{NaOH}$. The solutions and the mixture of solutions used also contained water glass (sodium silicate): in the case of soda glass $\left(\mathrm{SiO}_{2} / \mathrm{Na}_{2} \mathrm{O}=2.5\right)$; in the case of potassium glass $\left(\mathrm{SiO}_{2} / \mathrm{K}_{2} \mathrm{O}=3.0\right)$. The ratio of water glass to the base solution amounted to 2.5 in each case. The calcined clay was mixed with general construction sand (filler) in an amount of $50 \%$ by weight.

Alkaline activation of clay was conducted using both a sodium activator and a mixture containing potassium activator in view of the results of the tests [11] which showed that Na-activated geopolymers have a higher compression strength at ambient temperatures and higher resistance at elevated temperatures of up to $400^{\circ} \mathrm{C}$, compared to $\mathrm{K}$-activated polymers. K-activated geopolymers are characterized by higher compression strengths at $600^{\circ} \mathrm{C}$ than sodium geopolymers. In addition, the volume stability of potassium geopolymers is higher than that of the Na-activated geopolymers, and the loss of their mass is lower. Potassium-based geopolymers also have fewer surface cracks than when using Na. After 28 days of maturation, the generated samples were annealed at $1100^{\circ} \mathrm{C}$ and subjected to testing. The flexural strength was calculated according to EN 12390-5. The determination of permanent dimensional change because of heating was carried out according to EN 993-10: 2000 - method no. 2 (test temperature $800^{\circ} \mathrm{C}$ ). The density tests of sintered geopolymers were carried out using a helium pycnometer Pycnomatic ATC. Determination of flexural strength at elevated temperatures was conducted according to the EN 993-7: 2001 standard. Measurements of apparent density and porosity were carried out by means of the hydrostatic method.

\section{Results and discussion}

Figure 1 shows samples for tests made of alkaline activated calcium clay, after annealing at temperatures of $1100^{\circ} \mathrm{C}$. No cracks or other surface defects were observed on the surface of the samples. Tables 1 and 2 shows the results of density and porosity measurement. The samples were characterized by similar density (about $2.55 \mathrm{~g} / \mathrm{cm}^{3}$ ) both in the case of the sodium activator and the mixture of sodium and potassium activator. The total porosity was $38.78 \%$ for the $100 \mathrm{Na}$ sample and $36.24 \%$ for the $90 \mathrm{Na} / 10 \mathrm{~K}$ sample.

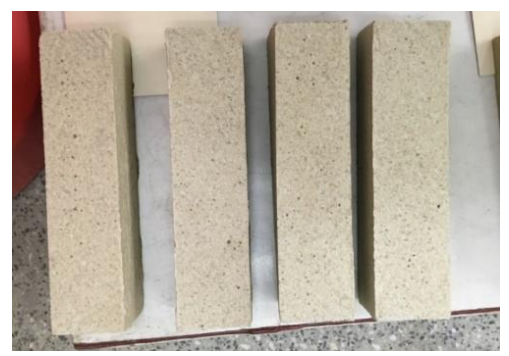

Fig. 1. Exemplary alkaline-activated composites based on calcium clay subjected to annealing at $1100^{\circ} \mathrm{C}$. 
Table 1. The results of porosity and apparent density measurement.

\begin{tabular}{|c|c|c|c|c|}
\hline $\begin{array}{c}\text { Sample } \\
\text { designation }\end{array}$ & $\begin{array}{c}\text { Apparent } \\
\text { density } \\
\left(\mathrm{g} / \mathrm{cm}^{3}\right)\end{array}$ & $\begin{array}{c}\text { Open } \\
\text { porosity } \\
\% \\
\end{array}$ & $\begin{array}{c}\text { Closed } \\
\text { porosity } \\
\%\end{array}$ & $\begin{array}{c}\text { Total } \\
\text { porosity }\end{array}$ \\
\hline $90 \mathrm{Na} / 10 \mathrm{~K}$ & 1.637 & 27.00 & 9.24 & 36.24 \\
\hline $100 \mathrm{Na}$ & 1.565 & 29.27 & 9.51 & 38.78 \\
\hline
\end{tabular}

Table 2. The results of density measurement using helium pycnometer.

\begin{tabular}{|c|c|}
\hline $\begin{array}{c}\text { Sample } \\
\text { designation }\end{array}$ & $\mathbf{g} / \mathbf{c m}^{\mathbf{3}}$ \\
\hline $\mathbf{9 0 ~ N a} / \mathbf{1 0 ~ K}$ & $2.56842 \pm 0.00233$ \\
\hline $\mathbf{1 0 0 ~ N a}$ & $2.55700 \pm 0.00112$ \\
\hline
\end{tabular}

Figure 2 shows the morphology of the $100 \mathrm{Na}$ sample. A glassy structure is visible, with pores occurring because of the geopolymer mass aeration over the course of the manufacturing process.

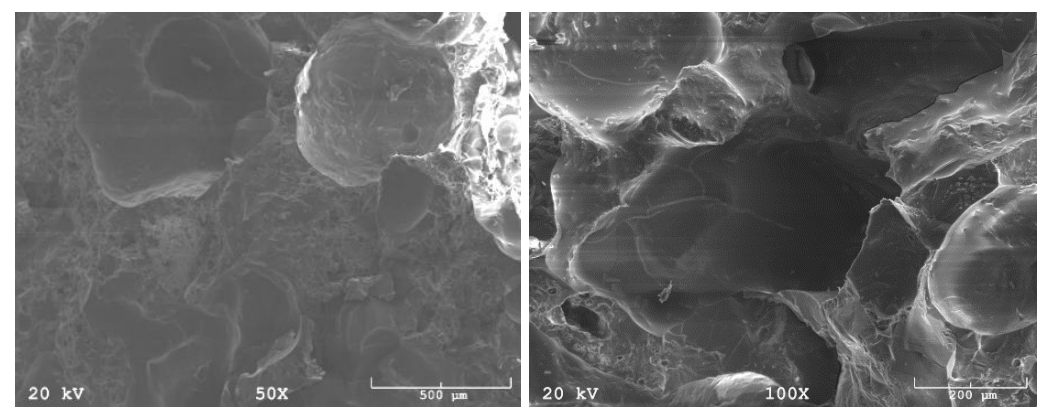

Fig. 2. The struture of composites based on calcium clay (100\% Na-activated) after heating at $1100^{\circ} \mathrm{C}$.

Table 3 shows the results of flexural strength tests carried out at ambient temperature and the temperature of $800^{\circ} \mathrm{C}$. In the case of a $100 \mathrm{Na}$ sample, a $38 \%$ decrease in the flexural strength was observed at an elevated temperature, whereas in the case of the $90 \mathrm{Na} /$ $10 \mathrm{~K}$ sample, the decrease amounted to $30 \%$.

Table 3. The results of the flexural strength tests.

\begin{tabular}{|c|c|c|}
\hline $\begin{array}{c}\text { Sample } \\
\text { designation }\end{array}$ & $\begin{array}{c}\text { Test at } \\
\text { ambient } \\
\text { temperature }\end{array}$ & $\begin{array}{l}\text { Test at } \\
\text { temp. } \\
800^{\circ} \mathrm{C}\end{array}$ \\
\hline $90 \mathrm{Na} / 10 \mathrm{~K}$ & 3.9 & 2.7 \\
\hline $100 \mathrm{Na}$ & 6.2 & 3.8 \\
\hline
\end{tabular}

Table 4 shows the results of a permanent dimensional change test due to heating. Significant differences were noted in relation to the type of activator used. When using $100 \% \mathrm{Na}$, the samples had a swelling of $0.473 \%$ as opposed to a shrinkage of $-1.65 \%$ observed in the case of the $90 \mathrm{Na} / 10 \mathrm{~K}$ sample. 
Table 4. Values of permanent dimensional change due to heating.

\begin{tabular}{|c|c|}
\hline $\begin{array}{c}\text { Sample } \\
\text { designation }\end{array}$ & $\begin{array}{c}\text { The average value of } \\
\text { the linear change } \\
{[\%]}\end{array}$ \\
\hline $\mathbf{9 0} \mathbf{~ N a} / \mathbf{1 0} \mathbf{~ K}$ & -1.65 \\
\hline $\mathbf{1 0 0} \mathbf{~ N a}$ & +0.473 \\
\hline
\end{tabular}

\section{Conclusion}

Calcium clay which is a by-product of a limestone plant can be an attractive material for the production of alkaline-activated binders. The alkali-activated generated composites based on sodium and potassium activators after heating at $1100^{\circ} \mathrm{C}$ are characterized by good values of flexural strength and good fire resistance. They can serve as an alternative to other refractory materials. Flexural strength tests at temperatures $800^{\circ} \mathrm{C}$ showed that materials made of calcium clay activated with a $100 \%$ sodium activator have a flexural strength of $3.8 \mathrm{MPa}$ (at ambient temperature, the strength equals 6.2 MPa). For the same composite, when using a sodium $(90 \%)$ and potassium activator $(10 \%)$, the flexural strength at $800^{\circ} \mathrm{C}$ is $2.7 \mathrm{MPa}$ (at ambient temperature, this strength equals $6.2 \mathrm{MPa}$ ). The use of various activators made it possible to find significant differences regarding the dimensional change due to heating. When using only the sodium activator, an increase of $0.473 \%$ was observed, while the application of activators of $90 \%$ sodium and $10 \%$ potassium resulted in a shrinkage of $1.65 \%$.

\section{References}

1. J. Davidovits, Geopolymer Chemistry and Applications, 4th ed., Geopolymer Institute, Saint-Quentin, 644 (2015)

2. L. Provis, J.S.J. van Deventer, Geopolymers: structure, processing, properties and industrial applications, 464 (2009)

3. M. Łach, K. Korniejenko, J. Mikuła, Procedia. Eng. 151, 6 (2016)

4. P. Chindaprasirt, U. Rattanasak, Clean Technol. Environ. Policy 20, 6 (2018)

5. H.Y. Zhang, V. Kodur, B. Wu, L. Cao, F. Wang, Constr. Build. Mater. 109, 17 (2016)

6. S.L. Hake, R.M. Damgir, S.V. Patankar, Adv. Civ. Eng., (2018)

7. L. Zuda, Z. Pavlík, P. Rovnaníková, P. Bayer, R. Černý, Int. J. Thermophys. 27, 1250 (2006)

8. M. Łach, K. Korniejenko, M. Hebdowska-Krupa, J. Mikuła, MATEC Web of Conferences 163, 8 (2018)

9. J. Davidovits, Geopolymer 2002 Conference 28, 29 (2002)

10. H. Xu, J. Van Deventer, Int. J. Miner. Process. 59, 247 (2000)

11. A. Hosan, S. Haque, F. Shaikh, J. Build. Engine. 8, 123 (2016) 